THE

MAKING

OF

MARTIN

LUTHER 


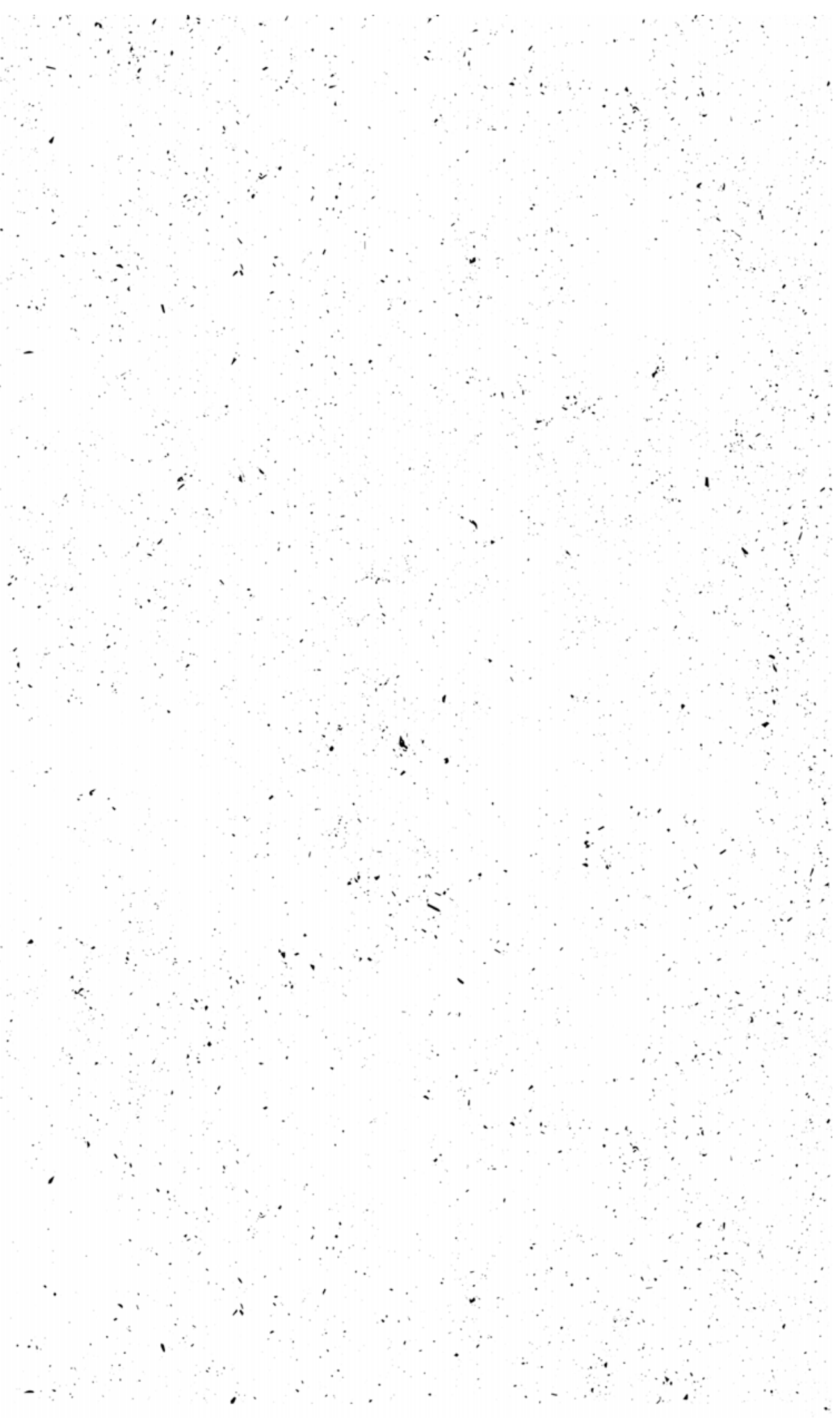



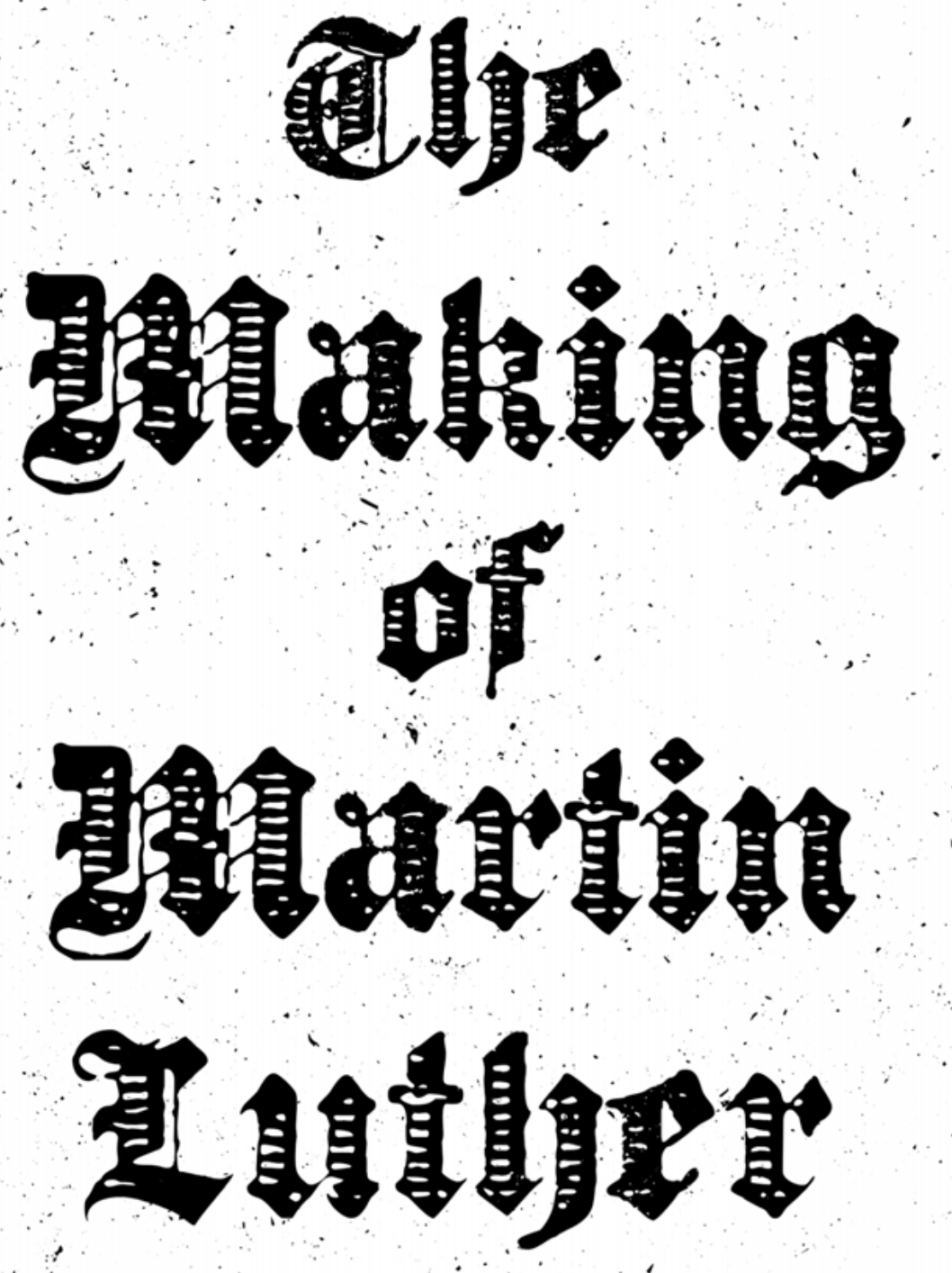

\section{RICHARD REX}

PRINCETON UNIVERSITY PRESS

PRINCETON AND OXFORD 
Copyright (c) 2017 by Princeton University Press

Published by Princeton University Press, 41 William Street, Princeton, New Jersey 08540

In the United Kingdom: Princeton University Press, 6 Oxford Street, Woodstock, Oxfordshire OX20 1TR press.princeton.edu

Jacket design by Amanda Weiss

All Rights Reserved

Library of Congress Cataloging-in-Publication Data

Names: Rex, Richard, author.

Title: The making of Martin Luther / Richard Rex.

Description: Princeton, NJ : Princeton University Press, 2017. Includes an index.

Identifiers: LCCN 2017009884 | ISBN 9780691155159 (hardcover : alk. paper)

Subjects: LCSH: Luther, Martin, 1483-1546. | Reformation. Classification: LCC BR325 .R524 2017 | DDC 284.1092 [B]—dc23

LC record available at https://lccn.loc.gov/2017009884

British Library Cataloging-in-Publication Data is available

This book has been composed in Archive Chased Black, Archive Garamond Exp, and Garamond Premier Pro

Printed on acid-free paper. $\infty$

Printed in the United States of America 
TO OLIVER,

and the cheerfulness that's always breaking in 
